\title{
PENGEMBANGAN APLIKASI MENGENAL AKSARA SATERA JONTAL BERBASIS ANDROID
}

\author{
Herfandi $^{1 *}$, Eri Sasmita Susanto ${ }^{2}$, Kevin Noanda Aditya Rudy Yanto ${ }^{3}$ \\ 1,2,3 Teknik Informatika, Universitas Teknologi Sumbawa \\ email: herfandi@uts.ac.id*
}

\begin{abstract}
Abstrak: Aksara satera jontal digunakan untuk menulis Bahasa Sumbawa yang diwujudkan berbentuk lambang, yang dimana setiap lambangnya memiliki artinya masing-masing. Aksara satera jontal dalam lingkup pemakaiannya semakin sempit, sehingga untuk mendapatkan informasi tentang aksara satera jontal semakin sulit. Salah satu kendalanya adalah kurangnya alat bantu untuk mengakomodasi pemikiran-pemikiran yang berhubungan dengan cara menggunakan aksara satera jontal. Usaha untuk melestarikan aksara satera jontal sudah ada dengan membuat aplikasi sehingga masyarakat dapat mempelajarinya, namun aplikasi tersebut masih memiliki kekurangan sehingga dikembangkannya Aplikasi Mengenal Aksara Satera Jontal Berbasis Android agar dapat memudahkan masyarakat untuk mempelajarinya. Penelitian ini menggunakan metode spiral dan dibangun dengan menggunakan Bahasa pemrograman java, dengan database SQLite, hasil dari penelitian ini yaitu Aplikasi Mengenal Aksara Satera Jontal Berbasis Android yang terdapat terjemahan, sejarah satera jontal, huruf satera jontal, dan tentang aplikasi dangan pengembangan adanya fitur voice.
\end{abstract}

Kata Kunci : Aplikasi, Aksara Satera Jontal, Berbasis Android

\begin{abstract}
Satera jontal script is used to write the sumbawa language which manifested in the form of a symbol, where each symbol has its own meaning. The scope of use of the satera jontal script is getting narrower, so it is increasingly difficult to get information about the satera jontal script. One of obstacles is the lack of tools to accommodate thoughts related to how to use the satera jontal script. Efforts to preserve satera jontal characters already exist by creating applications so that people can learn them, but this applications still has shortcoming so that the android based application of recognizing satera jontal script was developed in order to make it easier for the public to learn. This study uses the spiral method and is built using the java programming language, with a SQLite database, the results of this study are the android-based application of satera jontal script which contains translations, the history of satera jontal, satera jontal letters and about application with the development of voice features.
\end{abstract}

Keywords : Application, Satera Jontal Script, Android-based

\section{PENDAHULUAN}

Indonesia adalah negara yang sangat kaya akan budaya, hampir setiap daerah di Indonesia memiliki budayanya masing-masing terutama dalam hal tulisan atau aksara nusantara. Aksara nusantara merupakan salah satu warisan budaya yang patut dipertahankan. Aksara Nusantara sendiri merupakan aksara yang digunakan secara khusus untuk menuliskan bahasa daerah tertentu yang ada di Indonesia.

Sumbawa sebagai daerah di Indonesia yang terletak di Provinsi Nusa Tenggara Barat (NTB), memiliki tulisan daerah yang disebut aksara satera jontal. Aksara satera jontal digunakan untuk menulis Bahasa Sumbawa yang diwujudkan berbentuk lambang, yang dimana setiap lambang tersebut memiliki artinya masing-masing.

Seiring dengan perkembangan zaman, saat ini aksara satera jontal mulai ditinggalkan masyarakat karena kurangnya minat dari masyarakat untuk mempelajarinya. Aksara satera jontal dalam lingkup pemakaiannya semakin sempit, sehingga untuk mendapatkan informasi tentang aksara satera jontal semakin sulit.

Oleh karena itu dibuatlah aplikasi untuk membantu masyarakat dalam mengenal aksara satera jontal, namun aplikasi yang sudah ada yaitu aplikasi mengenal aksara satera jontal berbasis android masih memiliki kekurangan seperti kurangnya vocabulary atau kosa kata yang ada dan belum adanya fitur voice. Sehingga pada penelitian ini penulis ingin mengembangkan aplikasi sebelumnya yaitu aplikasi mengenala aksara satera jontal berbasis android menjadi lebih baik, dengan menambahkan kosa kata dan fitur voice agar dapat memudahkan pengguna dalam mempelajarinya.

\section{TINJAUAN PUSTAKA}

Dalam jurnal Hotman Pangaribuan dan Nanda 
Jarti, 2017 yang berjudul "Aplikasi Mengenal Aksara Batak Berbasis Android Menggunakan API Gesture". Bertujuan untuk melestarikan aksara batak yang penggunaannya pelan-pelan mulai menghilang karena perubahan jaman dan teknologi, oleh karena itu penting untuk melestarikan. Dengan tujuan akhir dari proses penelitian adalah memperkenalkan huruf batak toba berkarakter aksara nusantara, dengan fokus aksara batak toba yang menjadikan aksara batak mudah diakses dan dikenal karakternya oleh suku dan bangsa lain di seluruh dunia, termasuk masyarakat batak sendiri dengan menggunakan aplikasi berbasis android.[1]

\section{Dasar Teori}

\section{Pengembangan Aplikasi}

Menurut Miftahul 2015, Pengembangan Aplikasi adalah proses pembuatan program komputer atau serangkaian program untuk melakukan berbagai Vol. $x$ No. $x$ tugas yang diperlukan. Tidak hanya membuat program, pengembangan aplikasi juga sebuah proses untuk memperbaharui sebuah aplikasi yang sudah ada menjadi lebih baik. [2]

2. Aksara Satera Jontal

Menurut Fitrah Arisandi 2017, Satera jontal sendiri merupakan sebuah alat komunikasi yang diwujudkan berbentuk lambang atau simbol yang dimana setiap lambang tersebut memiliki arti sendiri. Dinamakan satera jontal, karena tulisan ini banyak dituliskan di atas Jontal atau Daun Lontar. Satera merupakan sastra dalam penerjemahan bahasa Indonesianya, untuk menulis satera jontal bukan menggunakan tinta namun bara apilah yang digunakan untuk menggores permukaan lontar tersebut, sehingga berbentuk kalimat.[3]

\section{METODE PENELITIAN}

1. Alur Penelitian

Metode yang digunakan dalam penelitian ini yaitu proses pengumpulan data dan pengembangan perangkat lunak. Adapun langkah-langkah yang digunakan adalah sebagai berikut:

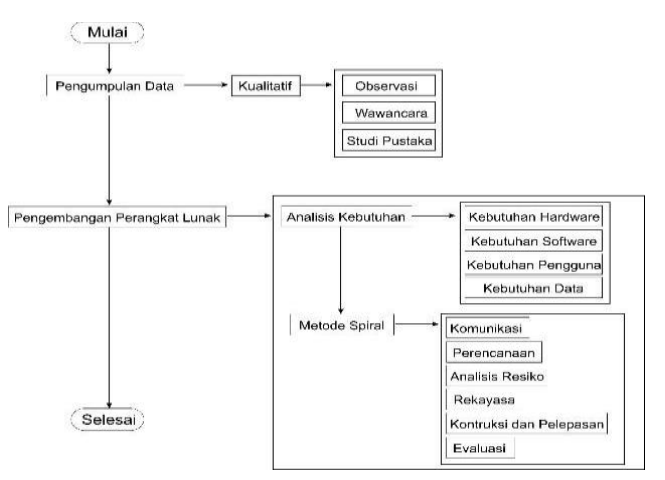

Gambar 1. Alur Penelitian

\section{Metode Pengumpulan Data}

Menurut Srivasta. A \& Thomson. S.B, 2009, Metode pengumpulan data merupakan cara yang digunakan untuk memperoleh data yang diperlukan dalam penelitian, metode pengumpulan data yang digunakan dalam penelitian skripsi ini adalah metode kualitatif. Karena metode ini bersifat dinamis, artinya selalu terbuka untuk adanya perubahan, penambahan, dan penggantian selama proses analisis.[4]

Adapun Langkah-langkahnya sebagai berikut:

a. Observasi

Pada tahapan ini penulis melakukan survei untuk mengumpulkan data agar dapat mengetahui seberapa paham masyarakat Sumbawa tentang aksara satera jontal, survei ini penulis lakukan disekitar tempat tinggal penulis dan Universitas Teknologi Sumbawa.

b. Wawancara

Pada tahap ini penulis melakukan wawancara tentang seberapa mengetahuinya masyarakat Sumbawa akan aksara satera jontal, sejarah satera jontal, bentuk simbol dari aksara satera jontal dan bagaimana cara menyusun kata menggunakan aksara satera jontal.

c. Studi Pustaka

Pada tahap ini penulis mengumpulkan data dengan cara mencari referensi atau literature yang mendukung untuk penelitian ini. Seperti jurnal, skripsi dan referensi yang ada di internet, yang berhubungan dengan aksara satera jontal dan sejenisnya.

\section{Metode Pengembangan Perangkat Lunak}

Metode pengembangan perangkat lunak yang digunakan dalam penelitian ini adalah metode spiral, yaitu metode yang menggabungkan pendekatan prototyping dan waterfall yang bersifat interaktif dengan aspek-aspek sistematis serta terkendali sehingga versi pengembangan perangkat lunak yang kurang lengkap menjadi semakin lengkap.

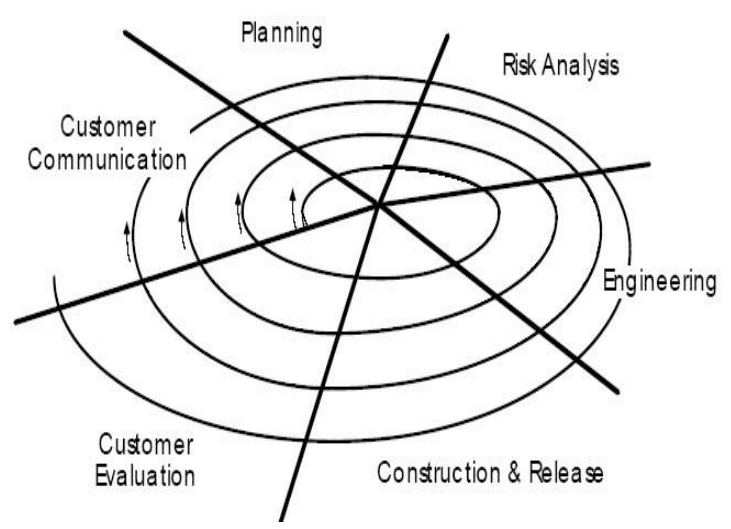

Gambar 2. Metode Spiral 
Berikut tahapan-tahapan menggunakan metode spiral sebagai metode pengembangan perangkat lunak (Aplikasi):

a. Customer Communication (Komunikasi)

Melakukan komunikasi kepada beberapa masyarakat asli Sumbawa dan masyarakat luar Sumbawa seperti mahasiswa tentang seberapa mengetahuinya mayarakat Sumbawa maupun luar Sumbawa akan aksara satera jontal.

b. Planning (Perencanaan)

Pada tahap ini ditentukan sumber-sumber untuk mencari informasi, penjadwalan pada aplikasi yang akan di implementasikan oleh Aplikasi Mengenal Aksara Satera Jontal Berbasis Android, serta merencanakan tentang bagaimana aplikasi berjalannya nantinya agar dapat memudahkan pengguna.

c. Risk Analysis (Analisis Resiko)

Pada tahap ini penulis mendefinisikan resiko, menentukan apa saja yang menjadi resiko yang akan dihadapi saat proses pengembangan aplikasi mengenal aksara satera jontal.

d. Engineering (Rekayasa)

Pembuatan prototipe atau pembangunan satu atau lebih representasi dari aplikasi mengenal aksara satera jontal, agar dapat mengetahui akan kebutuhan tambahan yang nantinya dapat membantu aplikasi mengenal aksara satera jontal berjalan dengan baik.

e. Construction \& Release (Konstruksi \& Pelepasan)

Pada tahap ini dilakukan pembangunan dan pengembangan aplikasi mengenal aksara satera jontal. Seperti diuji, diinstal dan diberikan tambahan untuk keberhasilan aplikasi.

f. Costumer Evaluation (Evaluasi)

User (pengguna) memberikan masukan berdasarkan hasil yang didapat dari tahap engineering dan instalasi, agar dapat membantu aplikasi mengenal aksara satera jontal berbasis android berjalan dengan baik.

\section{HASIL DAN PEMBAHASAN}

\section{Sistem berjalan}

Sistem yang sedang berjalan pada Aplikasi Mengenal Aksara Satera Jontal Berbasis Android akan dijelaskan pada gambar berikut ini:

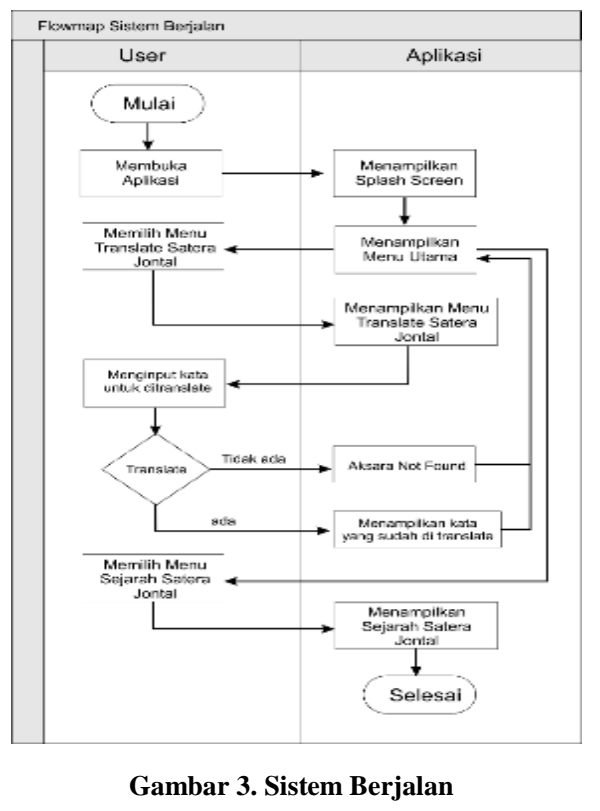

Sistem yang telah berjalan dari Aplikasi Mengenal Aksara Satera Jontal yang sebelumnya masih memiliki kekurangan, seperti kurangnya fitur voice sehingga tidak dapat mempermudah masyarakat Sumbawa khususnya dan masyarakat luar Sumbawa pada umumnya untuk memasukkan kata lebih cepat agar mudah diterjemahkan, sehingga dapat membantu masyarakat mempelajari aksara satera jontal sumbawa.

\section{Rancangan Sistem Usulan}

Adapun rancangan system usulan yang dilakukan dalam pengembangan Aplikasi Mengenal Satera Jontal Berbasis Android:

Gambaran Umum Aplikasi

Pada gambaran umum pengembangan aplikasi ini menjelaskan tentang bagian-bagian yang terdapat dalam Aplikasi Mengenal Aksara Satera Jontal Berbasis Android, yaitu: menu terjemahan, menu sejarah satera jontal, menu huruf satera jontal, menu tentang aplikasi. Adapun gambaran umum dari Aplikasi Mengenal Aksara Satera Jontal Berbasis Android sebagai berikut: 


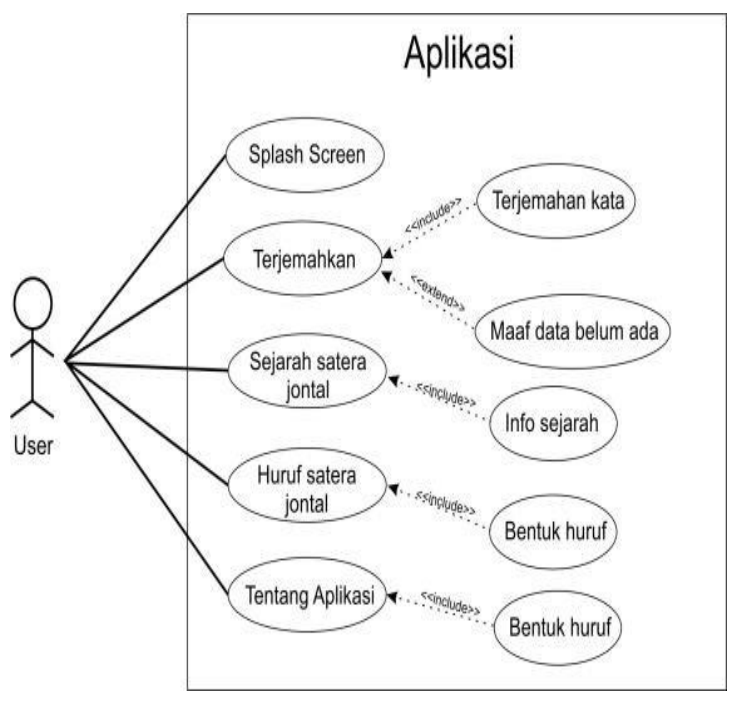

Gambar 4. Gambaran Umum Aplikasi

user dapat menggunakan aplikasi mengenal aksara satera jontal setelah user mengklik aplikasi kemudian keluar splash screen yang akan dilanjutkan ke dalam menu utama yang isinya terdapat menu terjemahan, menu sejarah satera jontal, menu huruf satera jontal, menu tentang aplikasi. Selain itu juga terdapat fitur tambahan yaitu fitur voice yang dapat memudahkan user untuk memasukkan kata agar dapat diterjemahkan ke dalam aksara satera jontal sumbawa.

\section{Implementasi Program}

Adapun implementasi program pada Pengembangan Aplikasi Mengenal Aksara Satera Jontal Berbasis Android adalah sebagai berikut:

a. Tampilan Splash Screen

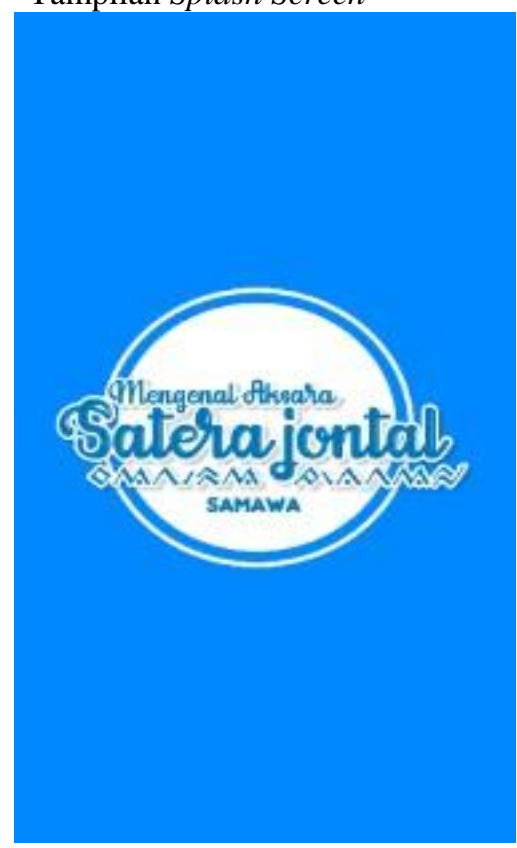

Gambar 5. Tampilan Splash Screen
Gambar diatas merupakan tampilan splash screen dari Aplikasi Mengenal Aksara Satera Jontal Berbasis Android, tampilan diatas akan muncul ketika user pertama kali membuka aplikasi. Kemudian akan diteruskan pada halaman menu utama pada aplikasi.

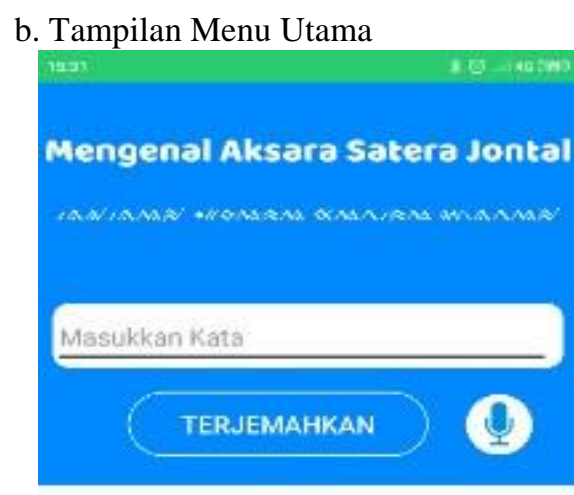

Sejarah Satera Jontal

\section{Sejarah Satera Jontal}

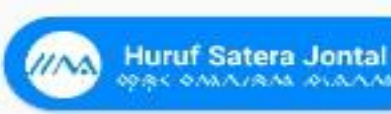

Tentang Aplikasi

Tentang Aplikasi

Gambar 6. Tampilan Menu Utama

Pada gambar diatas terdapat 4 menu yaitu menu terjemahkan, menu sejarah satera jontal, menu huruf satera jontal, menu tentang aplikasi. Setiap menu memiliki fungsinya masing-masing seperti menu terjemahkan dengan menginput kata dari Bahasa Indonesia dan diterjemahkan ke dalam aksara satera jontal sumbawa, menu sejarah satera jontal berfungsi untuk memberikan informasi tentang sejarah aksara satera jontal sumbawa, menu huruf satera jontal berfungsi memberikan informasi tentang bentuk aksara satera jontal sumbawa dan cara membacanya, menu tentang aplikasi berfungsi untuk menampilkan informasi tentang aplikasi mengenal aksara satera jontal berbasis android. 
c. Tampilan Terjemahkan

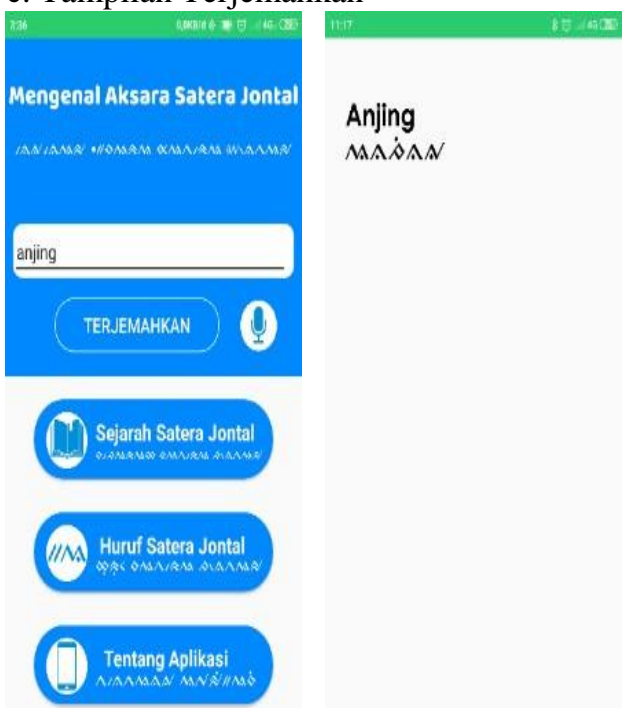

Gambar 7. Tampilan Terjemahkan

Menu ini berfungsi untuk menerjemahkan kata dari Bahasa Indonesia ke dalam bentuk aksara satera jontal sumbawa. User juga dapat menggunakan fitur voice agar mempermudah dalam menerjemahkan kata, setelah menginput kata user dapat mengklik tombol terjemahkan sehingga muncul tampilan kata yang sudah diinput beserta bentuk aksara satera jontal sumbawa.

\section{d. Tampilan Sejarah Satera Jontal}

\section{Sejarah Satera Jontal}

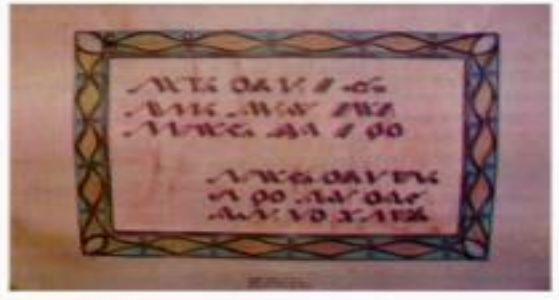

Satera Jontal adalah aksara tradisional Sumbawa, Nusa Tenggara Barat. Aksara ini digunakan untuk menulis bahasa

Sumbawa (basa samawa) yang dituturkan di pulau Sumbawa bagian barat. Nama satera jontal berasal dari kata Satera yang berarti sastra, dan jontal yang berarti daun lontar. nama ini meruiuk nada tulisan aksara in

\section{Gambar 8. Tampilan Sejarah}

Gambar di atas merupakan tampilan yang akan muncul ketika user mengklik menu sejarah satera jontal, menu ini berisikan informasi tentang sejarah dari aksara satera jontal sumbawa. e. Tampilan Huruf Satera Jontal

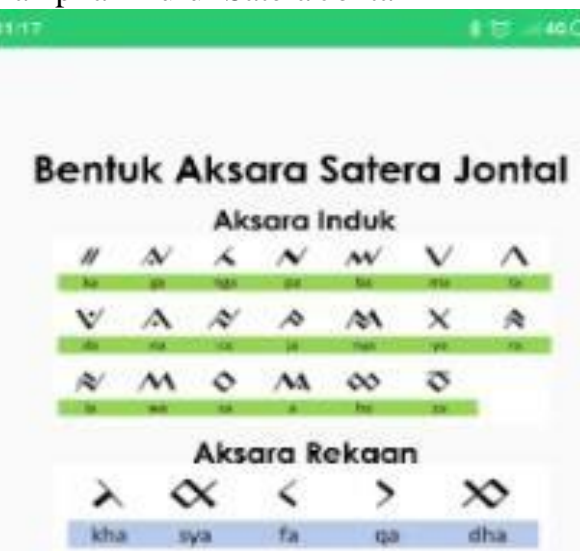

Variasi huruf ja, ra dan a

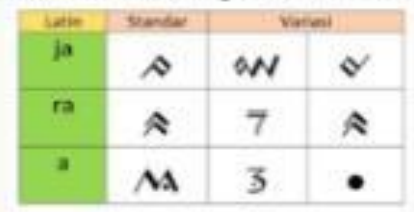

Tanda beca Aksara Satera Jontal

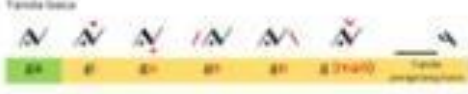

Gambar 9. Tampilan Huruf

Tampilan menu huruf satera jontal pada Aplikasi Mengenal Aksara Satera Jontal Berbasis Android, menu ini berisi informasi tentang bentuk huruf aksara satera jontal sumbawa dan cara membacanya.

f. Tampilan Tentang Aplikasi

\section{Tentang Aplikasi}

\section{Mengenal Aksara Satera Jontal}

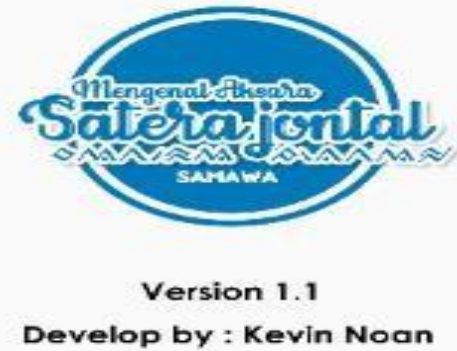

Gambar 10. Tampilan Tentang Aplikasi

Menu tentang aplikasi pada Aplikasi Mengenal Aksara Satera Jontal Berbasis Android ketika user mengklik menu tentang aplikasi, dalam menu ini terdapat informasi tentang aplikasi mengenal aksara satera jontal berbasis android. 


\section{KESIMPULAN DAN SARAN}

\section{Kesimpulan}

Kesimpulan yang dapat diambil dari skripsi ini yaitu Pengembangan Aplikasi Mengenal Aksara Satera Jonta Berbasis Android telah berhasil dibangun menggunakan bahasa pemrograman java dengan IDE android studio serta telah melewati tahap pengujian dengan menggunakan metode black box dengan kesuksesan 90\%. Setelah aplikasi dilakukan uji coba dengan smartphone telah berhasil menambahkan fitur voice sehingga dapat digunakan user, dengan terselesaikannya aplikasi ini dapat membantu untuk mempermudah masyarakat agar dapat mempelajarinya serta dapat membantu melestarikan aksara satera jontal sumbawa.

\section{Saran}

Berdasarkan kesimpulan yang telah diuraikan diatas, diperlukan adanya pengembangan agar aplikasi ini lebih baik lagi kedepannya yaitu dengan menambahkan fitur AR (Augmented Reality) agar dapat membantu mempermudah user untuk mencari kosa kata dalam bentuk aksara satera jontal.

\section{DAFTAR PUSTAKA}

[1] Pangaribuan. H and Jarti. N, 2017, “Aplikasi Mengenal Aksara Batak Berbasis Android Menggunakan API Gersture", Jurnal ISD Vol.2 No.2 Juli-Desember pISSN: 2477-863X eISSN: 2528-5114 2017.

[2] Miftahul. A, Muhammad. (2015). "Pengembangan Sistem Menggunakan Model Prototype pada Sistem Informasi Pemetaan Potensi Pertanian Berbasis Web". Skripsi. Program Studi Teknik Informatika Fakultas Sains dan Teknologi Universitas Islam Negeri Sunan Kalijaga Yogyakarta.

[3] Arisandi. F, 2017. "Rancang Bangun Aplikasi Mengenal Aksara Satera Jontal Berbasis Android". Universitas Teknologi Sumbawa, 2017

[4] Srivasta, A. \& Thomson, S.B. (2009). "Framework Analysis: A Qualitative Methodology for Applied Policy Research". Jurnal. JOAAG, Vol. 4, No. 2, Hal. 72-79. 